\title{
PENGARUH METODE ROUND ROBIN TERHADAP HASIL BELAJAR IPS SISWA KELAS VII
}

\author{
Nahdatul Hazmi \\ STKIP Abdi Pendidikan Payakumbuh \\ hazminahdatul@gmail.com
}

\begin{abstract}
ABSTRAK
Penelitian ini bertujuan untuk mengetahui pengaruh Round Robin terhadap hasil belajar siswa pada materi pelajaran IPS Kelas VII SMP Negeri 2 Kecamatan Situjoah Limo Nagari. Metode kuantitatif yang digunakan dalam penelitian ini adalah dengan pendekatan eksperimen, dimana desain penlitiannya adalah menggunakan kelas kontrol sebagai pembanding kelas penelitian. Berdasarkan hasil penelitian dari analisis diperoleh kesimpulan bahwa pembelajaran kooperatif teknik Round Robin dapat meningkatkan hasil belajar IPS siswa dengan baik. Hasil belajar siswa kelas VII di SMP N 02 Kec. Situjuah Limo Nagari dibagi dua kelompok yaitu pertama kelas eksperimen dimana nilai rata-ratanya adalah 72,9 dan yang kedua kelas kontrol dimana nilai rata-ratanya 60,3. Berarti nilai dari kelas eksprimen lebih tinggi dibandingkan nilai kontrol di karenakan kelas eksprimen memakai metode Round Robin sedangkan kelas control memakai konvensional. Simpulan, bahwa dengan mengunakan metode Round Robin pada mata pelajaran IPS dapat dikatakan berpengaruh signifikan terhadap hasil belajar.
\end{abstract}

Kata Kunci : Metode Round Robin, Hasil Belajar, IPS

\section{ABSTRACT}

This study aims to determine the effect of Round Robin on student learning outcomes in social studies subject matter VII Class SMP Negeri 2 Situjoah District Limo Nagari. The quantitative method used in this study is an experimental approach, in which the research design is to use a control class as a comparison of the research class. Based on the research results from the analysis it was concluded that the cooperative learning technique of Round Robin $d$ can improve students' social learning outcomes well. Class VII student learning outcomes in SMP N $02 \mathrm{Kec}$. Situjuah Limo Nagari was divided into two groups: the first was the experimental class where the mean score was 72.9 and the second was the control class where the average value was 60.3. Means the value of the experimental class is higher than the control value because the experimental class uses the Round Robin s method while the control class uses conventional. Conclusions, that by using the Round Robin method in social studies subjects can be said to have a significant effect on learning outcomes.

Keywords: Round Robin Method, Learning Outcomes, Social Studies 


\section{PENDAHULUAN}

Pembelajaran pada dasarnya merupakan upaya untuk mengarahkan peserta didik ke dalam proses belajar sehingga mereka dapat memperoleh tujuan belajar sesuai dengan apa yang diharapkan. Pembelajaran hendaknya memperhatikan kondisi individu anak karena mereka yang akan belajar karena peserta didik merupakan individu yang berbeda satu sama lain, memiliki keunikan masing-masing yang tidak sama dengan orang lain (Sobur: 2013).

Oleh karena itu, pembelajaran hendaknya memperhatikan perbedaaanperbedaaan individual anak tersebut, sehingga pembelajaran benar-benar dapat merubah kondisi anak dari yang tidak tahu menjadi tahu dari yang tidak paham menjadi paham serta dari yang berperilaku kurang baik menjadi baik. Kondisi nyata anak seperti ini, selama ini kurang mendapat perhatian dikalangan pendidik.

Berbicara tentang proses pendidikan sudah tentu tidak dapat dipisahkan dengan semua upaya yang harus dilakukan untuk mengembangkan sumber daya manusia yang berkualitas. Fungsi pendidikan adalah menyiapkan peserta didik. Pendidikan adalah suatu proses dalam rangka mempengaruhi peserta didik supaya mampu menyesuaikan diri sebaik mungkin dengan lingkungannya, dan dengan demikian akan menimbulkan perubahan dalam dirinya yang memungkinkan untuk berfungsi secara baik dalam kehidupan masyarakat.

Hal ini terlihat dari perhatian sebagian guru atau pendidikan yang cenderung tidak memperhatikan kelas secara keseluruhan, tidak perorangan atau kelompok anak sehingga perbedaaan individual kurang mendapat perhatian. Gejala yang lain terlihat pada kenyataan banyaknya guru yang mengunakan metode pengajaran yang cenderung sama setiap kali pertemuan dikelas berlangsung.

Pembelajaran yang kurang memperhatikan perbedaaan individual anak dan didasarkan pada keinginan guru, akan sulit untuk dapat mengantarkan peseta didik ke arah pencapaian tujuan pembelajaran. Kondisi seperti inilah yang pada umumnya terjadi pada pembelajaran konvensional. Konsekuensi dari pendekatan pembelajaran seperti ini adalah terjadinya kesenjangan yang nyata antara anak yang cerdas dan anak yang kurang cerdas dalam pencapaian tujuan pembelajaran. Kondisi seperti ini mengakibatkan tidak diperolehnya ketuntasan dalam belajar, sehingga sistem belajar tuntas terabaikan. Hal ini membuktikan terjadinya kegagalan dalam proses pembelajaran disekolah.

Seiring dengan tanggung jawab professional pengajar dalam proses pembelajaran maka dalam melaksanakan kegiatan pembelajaran setiap guru dituntut untuk selalu menyiapkan segala sesuatu yang berhubungan dengan program pembelajaran yang akan berlangsung. Tujuannya adalah agar kegiatan pembelajaran 
dapat berjalan secara efektif dan efesien yaitu tujuan akhir yang diharapkan dapat dikuasai oleh semua peserta didik.

Dalam rangka pencaapaian tujuan pembelajaran ini, setiap guru dituntut untuk benar-benar memahami metode pembelajaran yang akan diterapakannya. Sehubungan dengan hal tersebut, seorang guru perlu memikirkan metode atau pendekatan yang akan digunakan. Pemilihan metode pembelajaran yang tepat yaitu dengan situasi dan kondisi yang dihadapi akan berdampak pada tingkat penguasaan atau hasil belajar siswa, seorang guru dapat mengunakan beberapa metode pembelajaran untuk meningkatkan hasil belajar siswa salah satunya adalah dengan mengunakan metode Round Robin yaitu cara belajar siswa yang tujuannya yaitu untuk memotivasi, mengaktifkan dan menceriakan suasana kelas sehingga mampu melatih peserta didik berfikir kritis dan kreatif serta memupuk sikap berani pada peserta didik untuk mengemukakan pendapat sehingga hasil belajar akan lebih baik.

Berdasarkan hasil observasi awal terhadap siswa kelas VII di SMPN 02 Kecamatan Situjuah Limo Nagari, diperoleh hasil bahwa ketika proses pembelajaran berlangsung guru mata pelajaran IPS masih mengunakan Metode mengajar guru masih kurang efektif karena masih memakai metode konvensional . Terjadinya kesenjangan yang nyata antara anak-anak yang cerdas dengan anak kurang cerdas. Dari situ ketuntasan dalam belajar ketuntasan dalam belajar terbaikan sehingga ketika berlangsungnya proses pembelajaran kebanyakan siswa sedikit yang ikut berpatisipasi dan pasif di dalam kelas, melihat fenomena seperti ini tentu saja menciptakan suasana kelas yang statis, menonton, dan membosankan. Kemudian juga hasil belajar siswa SMPN 02 Kecamatan Situjuah Limo Nagari kelas VII yang belum memenuhi nilai rata-rata dari kriteria ketuntasan minimal (KKM) yang ditentukan yaitu 70 ,bahkan yang mendapat hasil belajar dibawah standar KKM diatas 70\%.

Strategi merupakan komponen pembelajaran yang memungkinkan terlaksanakan metode-metode terpilih untuk menyajikan bahan ajar selama pembelajaran (Rianto:2002). Ilmu dan kiat dalam memanfaatkan segala sumber yang dimiliki dan atau yang dapat dikerahkan untuk mencapai tujuan yang telah ditetapkan (Rianto:2002). Lebih lanjut ditunjukan bahwa strategi pembelajaran banyak ragamnya, ibarat berada satu rentengan (continuum) antara dua ujung yang saling berlawanan, yaitu ekspositori dan diskoveri/inkuiri. Strategi pembelajaran adalah suatu kegiatan pembelajaran yang harus dikerjakan guru dan siswa agar tujuan pembelajaran dapat dicapai secara efektif dan efisien.

Lalu ciri strategi yang berpeluang bagi peserta didik untuk berperan aktif selama proses pembelajaran, antara lain: 1)Setiap tahapan kegiatan memungkinkan pengggunaan berbagai macam sumber belajar,metode dan media pembelajaran; 
2)Selama proses pembelajaran mencerminkan kegiatan belajar yang beragam baik secara individu maupun kelompok; 3)Dalam kegiatan pembelajaran memungkinkan peserta didik belajar bekerja sama dan slaing tukar-menukar pengalaman; 4)Setiap tahapan kegiatan pembelajaran memberikan pengalaman belajar (learnig Expriences) dan keberaniannya untuk menjadi pembicara sekaligus pendengar yang baik; 5)Setiap tahapan kegiatan pembelajaran memungkinkan bagi peserta didik untuk menumbuhkembangkan kemampuannya dalam berpikir secara kritis,kreatif,inovatif, dan produktif; 6)Setiap tahapan kegiatan pembelajaran memotivasi peserta didik untuk mengkaji lebih jauh bahan-bahan yang telah dan sedang dipelajari; 7)Dalam proses pembelajaran peserta didik memperoleh berbagai macam fasilitas belajar untuk melakukan kegiatan praktik dan latihan; 8)Dalam proses pembelajaran peserta didik memperoleh kesempatan untuk berdialog dengan dirinya sendiri dan lingkungan sekitar (fisik dan social) secara bebas (Rianto:2002).

Dalam kelas dengan metode belajar tradisional atau ceramah, siswa bekerja secara individu dan cenderung mengandalkan guru dalam menjelaskan seluruh bahan mata pelajaran. Sedangkan dalam Round Robin siswa dapat berinteraksi dengan siswa yang lainnya dalam membahas atau berdiskusi tentang apa yang dipelajari dalam kelas, selain itu siswa juga dapat memiliki ketrampilan sosial, karakter yang baik dan mengasah kecerdasan emosional, Sari \& Maimunah (2017).

\section{METODE PENELITIAN}

Metode Round Robin yakni cara belajar siswa dimana tujuannya yaitu untuk mendorong peserta didik untuk berfikir dan memberikan respon bergilir atau jawaban bergilir dengan sebuah kata atau pernyataan singkat (Hisyam:2008). Dapat disimpulkan metode Round Robin adalah cara belajar siswa dimana tujuannya yaitu untuk mendorong peserta didik untuk berpikir dan memberikan respon bergilir atau jawaban bergilir dengan sebuah kata atau pernyataan singkat.Adapun langkahlangkah dalam penerapan metode Round Robin ini adalah; 1)Siswa dikelompokkan dalam kelompok beranggotakan 4-6 orang siswa; 2)Siswa duduk berkeliling membentuk lingkaran pada masing-masing kelompok; 3)Guru mengajukan sebuah pertanyaan yang jawaban ganda atau suatu topik yang dapat dipakai dalam curah pendapat; 4)Guru mengatur waktu pencatat waktu (stopwatch) sesuai waktu yang disepakati mislanya 10 detik untuk setiap siswa dan 2 menit untuk seluruh tim (bergantung kemungkinan panjang pendeknya jawaban, serta tingkat kesukaran soal yang diajukan guru); 5)Siswa duduk disekeliling meja menyampaikan jawaban yang mungkin secara bergiliran sesuai waktu yang disediakan; 6)Siswa melanjutkan curah pendapat itu sampai waktu yang disediakan untuk pertanyaan tersebut habis; 7)Guru 
mendengarkan jawaban setiap siswa sepanjang pelaksaaan dan membuat klarifikasi dan penjelasan yang diperlukan bagi kebaikan pemahaman siswa bila diperlukan. (Hisyam:2008)

Metode Round Robin tidak terlepas dari kelemahan disamping kelebihan yang dimilikinya, kelemahan Metode Round Robin yaitu: 1)Kelas menjadi ribut; 2)Dalam mengimpelementasikannya, memerlukan waktu yang panjang sehingga guru sulit menyesuaikan dengan waktu yang ditentukan; 3)Terkadang sulit dalam pelaksanaan karena guru harus mempersiapkan handout atau perencanaan terlebih dahulu, dengan memilah bagian atau materi mana yang harus dikosongkan dan pertimbangan kesesuain materi dengan kesiapan siswa untuk belajar dengan metode pembelajarn tersebut; 4)Menutut para guru untuk lebih menguasai materi lebih luas lagi dari standar yang telah ditetapkan.

Adapun kelebihan Metode Round Robin yaitu: 1) Dapat memotivasi dan mewujudkan para peserta didik boleh bergerak dan sekaligus dapat mengaktifkan dan menceriakan suasana; 2)Mampu melatih peserta didik mendengar arahan dengan teliti,cepat,dan tepat; 3)Melatih peserta didik berfikir secara kritis dan kreatif; 4)Memupuk sikap berani para peserta untuk mengemukakan pendapat.

Dari kelebihan dan kekurangan di atas, dapat ditarik kesimpulan bahwa kelebihan dari metode Round Robin adalah memotivasi dan mewujudkan para peserta didik boleh bergerak dan sekaligus dapat mengaktifkan dan menceriakan suasana, mampu melatih peserta didik mendengar arahan dengan teliti, cepat, dan tepat. Melatih peserta didik berfikir secara kritis dan kreatif serta memupuk sikap berani para peserta untuk mengemukakan pendapat. Sedangkan untuk kekurangan dari metode Round Robin yaitu akan menghabiskan banyak waktu dan membuat kelas menjadi ribut.

\section{HASIL PENELITIAN}

Jenis penelitian ini adalah penelitian kuantitatif dengan mengelola data secara eksperimen. Dimana peneliti akan bekerja dengan angka-angka sebagai perwujudan gejala yang diamati (Sugiyono:2014). Peneltian ini bertujuan untuk mengetahui metode Round Robin dalam meningkatkan hasil belajar siswa, hal ini dapat dilihat dari jawaban siswa pada soal-soal yang diujikan, sesudah siswa mengunakan metode Round Robin dikelas.

Pada penelitian ini yang menjadi kelas eksperimen adalah kelas VII.1 terdiri dari 25 orang siswa diantaranya 16 Laki-laki dan 9 perempuan. Sebelum dilaksanakan ekperimen ini terlebih dahulu dilihat hasil belajar siswa pada mid semester genap tahun ajaran 2017/2018. Setelah diketahui skor hasil belajar siswa 
kelas VII.1 pelajaran IPS Terpadu adalah 69,8 dengan KKM 70. Dilihat distribusi frekuensi hasil belajar siswa kelas eksperimen sebelum diterapkan metode pemebelajaran Round Robin seperti dibawah ini:

Tabel 1

Distibusi Frekuensi Hasil Ujian Mid Semester Genap Tahun Ajaran 2017/2018.

\begin{tabular}{ccc}
\hline Kelas interval & Frekuensi & Persen(\%) \\
\hline $30-69$ & 8 & $32 \%$ \\
\hline $70-85$ & 11 & $44.89 \%$ \\
\hline $86-100$ & 6 & $23.11 \%$ \\
\hline Total & 25 & $100 \%$ \\
\hline
\end{tabular}

Dari data diatas dilihat hasil belajar siswa masih banyak yang dibawah KKM. Dapat dilihat kurva normal sebagai berikut :

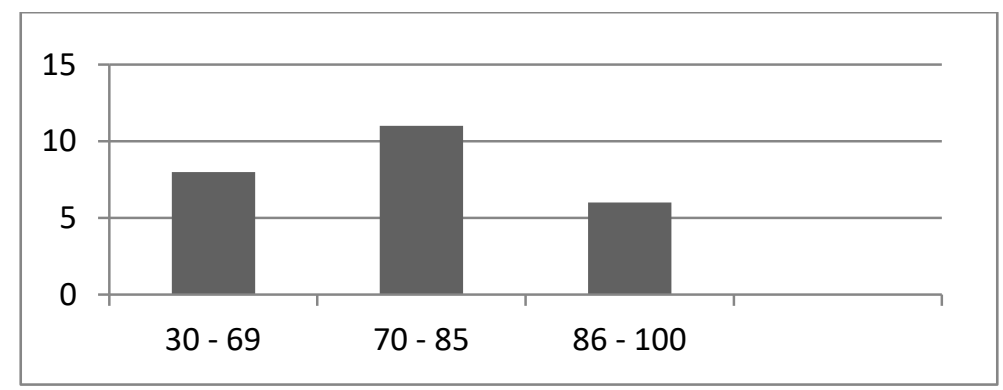

Gambar 1

Histogram Kelas Eksperimen Ujian Tengah Semester

Keterangan histogram diatas : $30-69$ berjumlah 8 orang sedangkan 70-85 berjumlah 11 orang dan $86-100$ berjumlah 6 orang. Berarti siswa yang tidak tuntas /dibawah KKM berjumlah 8 orang.Secara keseluruahan hasil belajar kelas eksperimen adalah rata-rata: 72,9 simpang baku : 15.63 ,Variasi : 264.38

Untuk melihat distribusi frekuensi hasil belajar kelas eksperimen disajikan dibawah ini :

Tabel 2

Distribusi Frekuensi Hasil Belajar Kelas Eksperimen

\begin{tabular}{ccc}
\hline Kelas interval & Frekuensi & Persen(\%) \\
\hline $41-50$ & 4 & $16 \%$ \\
\hline $51-60$ & 2 & $8 \%$ \\
\hline $61-70$ & 2 & $8 \%$ \\
\hline $71-80$ & 9 & $36 \%$ \\
\hline $81-90$ & 5 & $20 \%$ \\
\hline
\end{tabular}




\begin{tabular}{ccc}
\hline $91-100$ & 3 & $12 \%$ \\
\hline Total & 25 & $100 \%$ \\
\hline
\end{tabular}

Dari data pada tabel diatas dapat dilihat bahwa adalah dilakukan perlakuan terhadap kelas ekperimen dengan penerapan metode pembelajaran Round Robin dapat disimpulkan nila rata siswa sudah banyak diatas KKM yaitu 70. Selain itu dapat dilihat histogram dan kurva normal hasil belajar kelas ekperimen total seperti dibawah ini:

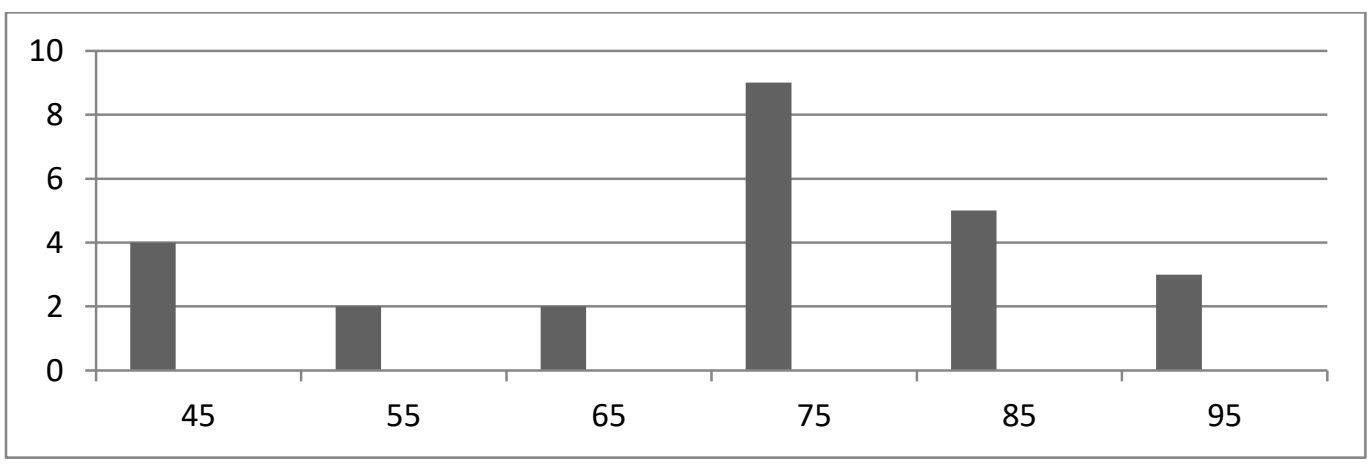

Gambar 2

Histogram Kelas Ekperimen

Keterangan histogram diatas : 41-50 berjumlah 4 orang, lalu 51-60 berjumlah 2 orang ,lalu 61-70 berjumlah 2 orang,lalu 71-80 berjumlah 9 orang, lalu 81-90 berjumlah 5 orang dan 91-100 berjumlah 3 orang. Berarti siswa yang tidak tuntas berjumlah 8 orang.

Pada kelas kontrol Secara keseluruhan hasil belajar siswa VII.2 yang mengunakan metode konvensional diperoleh rata-rata : 60,3 simpang baku: 17.73, varians : 313.17. Untuk melihat distribusi frekuensi hasil belajar kelas kontrol disajikan dibawah ini :

Tabel 3

Distribusi Frekuensi Hasil Belajar Kelas Kontrol

\begin{tabular}{ccc}
\hline Kelas interval & Frekuensi & Persen(\%) \\
\hline $31-40$ & 5 & 21.73 \\
\hline $41-50$ & 3 & 13.04 \\
\hline $51-60$ & 4 & 17.39 \\
\hline $61-70$ & 2 & 8.69 \\
\hline $71-80$ & 6 & 26.08 \\
\hline $81-90$ & 3 & 13.04 \\
\hline
\end{tabular}




\begin{tabular}{ccc}
\hline Total & 23 & $100 \%$ \\
\hline
\end{tabular}

Dilihat dari tabel diatas,maka hasil belajar siswa yang menggunakan metode konvesional masih banyak siswa yang nilianya masih dibawah KKM yaitu 70 .

Berdasarkan tabel diatas dapat dilihat kurva normal dari hasil belajar kelas Kontrol sebagai berikut :

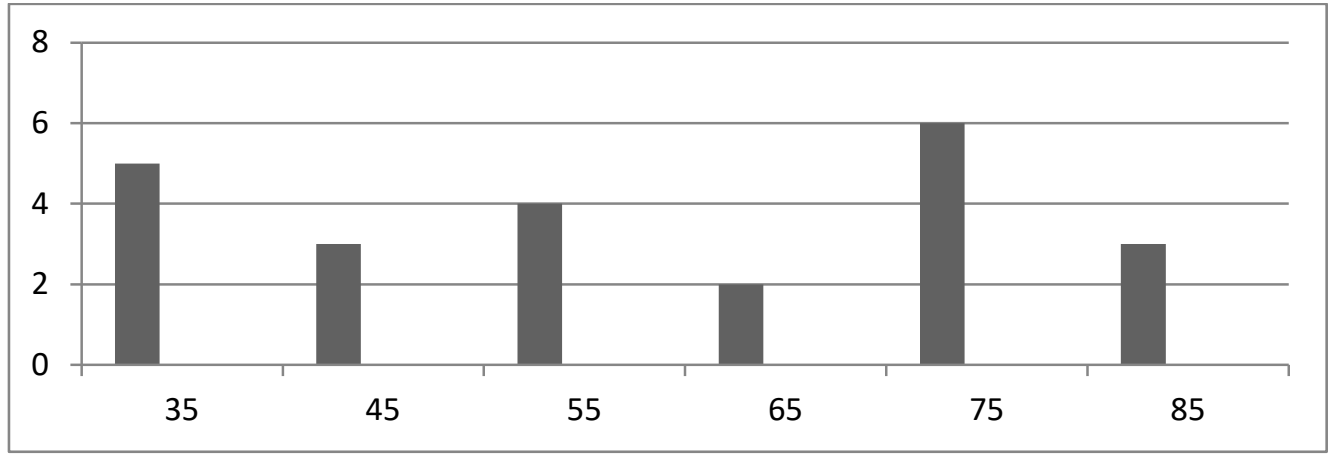

Gambar 3

Histogram Kelas Kontrol

Keterangan histogram diatas : 31-40 berjumlah 5 orang, lalu 41-50 berjumlah 3 orang, lalu 51-60 berjumlah 4 orang, lalu 61-70 berjumlah 2 orang, lalu 71-80 berjumlah 6 orang dan $81-90$ berjumlah 3 orang. Berarti siswa yang tidak tuntas berjumlah 14 orang.

Setelah dilakukan penelitian pada kelas sampel maka diperoleh hasil belajar siswa kelas eksperimen dan kelas kontrol, seperti pada tabel di bawah ini :

Tabel 4

Hasil Belajar Siswa Kelas Eksperimen Dan Kelas Kontrol

\begin{tabular}{cccc}
\hline \multirow{2}{*}{ Parameter } & \multicolumn{2}{c}{ Kelas } & \multirow{2}{*}{ keterangan } \\
\cline { 2 - 3 } & Eksperimen & Kontrol & $\mathrm{X} 1=\mathrm{X} 2$ \\
\hline Rata-rata nilai tes akhir & \multicolumn{1}{c}{$\mathrm{X}_{1}=72,9$} & $\mathrm{X}_{2}=60,3$ & Berdistribusi normal \\
\hline \multirow{2}{*}{ Uji Normalitas } & $\begin{array}{c}\mathrm{L}_{\mathrm{h}}=0,1432 \\
\mathrm{~L}_{\mathrm{t}}=0,173\end{array}$ & $\begin{array}{c}\mathrm{L}_{\mathrm{h}}=0,0644 \\
\mathrm{~L}_{\mathrm{t}}=0,173\end{array}$ & \multirow{2}{*}{ Varians homogen } \\
\hline \multirow{2}{*}{ Uji Homogenitas } & \multicolumn{2}{c}{$\mathrm{F}_{\mathrm{h}}=1,18$} & \\
\hline \multirow{2}{*}{ Uji Hipotesis } & $\mathrm{F}_{\mathrm{t}}=1,98$ & \multirow{2}{*}{$\mathrm{H} 1$ diterima } \\
\hline
\end{tabular}

Dari data tabel di atas terdapat perbandingan yang signifikan dari kelas eksperimen dengan penerapan metode Round Robin memperoleh skor hasil belajar 
siswa 72,9 sedangkan pada kelas control yang hanya menerapkan pembelajaran konvensional memperoleh skor hasil belajar 60,3. Sehingga dapat disimpulkan adanya pengaruh positif dari penerapan metode Round Robin dibandingkan dengan pembelajaran konvensional. Untuk dapat menarik kesimpulan hasil penelitian dilakukan uji-t. Syarat untuk mengunakan uji-t adalah data harus bedistribusi normal dan homogeny. Sehingga terlebih dahulu dilakukan pengujian normalitas dan homogenitas, setelah kedua pengujian tersebut selesai dilakukan maka bisa dilakukan uji hipotesis.

Uji Normalitas Pada uji normalitas ini digunakan uji liliefors seperti yang tertera pada teknik analisa data. Berdasarkan uji normalitas kelas sampel diperoleh harga $L_{h}$ dan $L_{t}$ pada taraf nyata seperti pada tabel berikut :

Tabel 5

Hasil Uji Normalitas Kelas Eksperimen

\begin{tabular}{cccccc}
\hline Kelas & $\mathbf{N}$ & $\boldsymbol{\alpha}$ & $\mathbf{L}_{\mathbf{h}}$ & $\mathbf{L}_{\mathbf{t}}$ & kesimpulan \\
\hline Ekperimen & 25 & 0.05 & 0.1432 & 0.173 & normal \\
\hline
\end{tabular}

Berdasarkan data pada tabel diatas terlihat bahwa kelas sampel memiliki $\mathrm{L}_{\mathrm{h}}<$ $\mathrm{L}_{\mathrm{t}}$ yang berarti antara kelas berdistribusi normal.

Uji Homogenitas dilakukan untuk mengetahui kedua kelompok data apakah memiliki varians yang homogen atau tidak maka dilakukan uji $F$. Hasil analisis homogenitas sampel dapat dilihat pada tabel di bawah ini.

Tabel 6

Hasil Uji Homogenitas kelas sampel

\begin{tabular}{cccccccc}
\hline Kelas & $\mathbf{N}$ & $\mathbf{X}$ & $\mathbf{S}$ & $\mathbf{S}^{2}$ & $\mathbf{F}_{\text {hitung }}$ & $\mathbf{F}_{\text {tabel }}$ & Keterangan \\
\hline ekperimen & 25 & 72.9 & 15.63 & 264,38 & 1,18 & 1,91 & Homogen \\
\hline
\end{tabular}

Berdasarkan tabel 8 diatas terlihat bahwa kelas sampel memiliki $\mathrm{F}_{\text {hitung }}<\mathrm{F}_{\text {tabel }}$ berarti kedua kelas sampel mempunyai varians yang homogen.

Uji Hipotesis dilakukan setelah uji normalitas dan homogenitas, karena hasil normalitas data berdistribusi normal dan uji homogenitas data dikatakan homogen, kemudian dilakukan uji hipotesis mengunakan $u j i$-t. dari hasil analisis diperoleh data seperti tabel dibawah ini: 
Tabel 7

Ringkasan Uji Hipotesis

\begin{tabular}{cc}
\hline Kelas eksperimen & Kelas control \\
\hline $\mathrm{N}_{1}: 25$ & $\mathrm{~N}_{2}: 23$ \\
\hline $\mathrm{X}_{1}: 72,9$ & $\mathrm{X}_{2}: 60,3$ \\
\hline $\mathrm{S}^{2}: 264,38$ & $\mathrm{~S}^{2}: 313,7$ \\
\hline \multicolumn{3}{c}{$\mathrm{T}_{\mathrm{h} \text { itung }}=2,59$} \\
$\mathrm{~T}_{\mathrm{t} \text { abel }}=1,68$ \\
\hline Kesimpualn $: \mathrm{H}_{1}$ diterima karena $\mathrm{T}_{\text {hitung }}>\mathrm{T}_{\text {tabel }}$ \\
\hline
\end{tabular}

Hasil dari uji hipotesis diatas diperoleh $\mathrm{T}_{\text {hitung }}: 2,60$ sedangkan $\mathrm{T}_{\text {tabel }}$ pada taraf signifikan 0,05 adalah 1,68 , berarti $\mathrm{T}_{\text {hitung }}>\mathrm{T}_{\text {tabel }}$ sehingga $\mathrm{H}_{1}$ diterima dan $\mathrm{H}_{0}$ ditolak.

Dari hasil uji hipotesis dapat ditarik kesimpulan bahwa terdapat pengaruh yang signifikan setelah pembelajaran menggunakan metode Round Robin terhadap hasil belajar siswa. Sejalan dengan hasil penelitian Sari \& Maimunah (2017) bahwa analisis penelitian membuktikan bahwa ada pengaruh metode kooperatif tipe Round Robin terhadap prestasi belajar pada siswa, dimana pengaruh tersebut merupakan pengaruh yang positif, sehingga dapat diartikan bahwa metode pembelajaran kooperatif tipe Round Robin dapat meningkatkan prestasi belajar atau hasil belajar pada siswa dibandingkan dengan metode belajar yang dilakukan secara tradisional.

\section{PEMBAHASAN}

Berdasarkan deskripsi data hasil penelitian, kelompok siswa yang mengikuti pembelajaran dengan mengunakan metode Round Robin memiliki rata-rata skor hasil belajar IPS yang lebih tinggi dibandingkan dengan kelompok siswa yang mengikuti pembelajaran dengan menerapkan metode konvensional. Tinjuan ini berdasarkan pada rata-rata skor hasil siswa yang menerapkan metode Round Robin adalah 72,9 dan rata-rata skor hasil belajar siswa yang menerapkan model pembelajaran konvensional adalah 60,3.

Perbedaan hasil belajar IPS yang signifikan antara siswa yang mengikuti pembelajaran dengan mengunakan metode Round Robin dan siswa yang mengikuti pelajaran mengunakan metode konvesional disebabkan karena perbedaan perlakuan pada langkah-langkah pembelajaran dan pemyampaian materi. Metode Round Robin lebih menekankan pada pengembangan kesiapan siswa dalam mengikuti pembelajaran dan melatih siswa untuk berani berkerja sama, sedangkan metode konvensional menekankan pada hafalan. Dengan adanya perbedaan perlakuan pada langkah-langkah ini dikontribusikan dapat berpengaruh baik dalam meningkatkan hasil belajar siswa. 
Pembelajaran dengan menggunakan metode Round Robin memiliki langkah sebagai berikut, tahap persiapan (menyiapkan materi dan pertanyaan), pembukaan (penyampaian tujuan pembelajaraan dan penyampaian materi), pelaksaanaan (membaca pembelajaraan dan tanya jawab) dan penutup (kesimpulan,refleksi dan evaluasi). Dapat disimpulkan penerapan metode Round Robin menjadikan siswa aktif dalam pembelajaran sehingga proses pembelajaran menjadi lebih bermakna. Pembelajaran bermakna mendorong siswa untuk lebih bermotivasi untuk lebih termotivasi dalam belajar, apabila telah termotivasi akan berdampak positif terhadap hasil belajar. Dari empat langkah diatas penerapan metode Round Robin terdapat dua tahapan penting dalam pembelajaran ini yang dapat mengkontribusikan meningkatkan semangat belajar siswa dalam mengikuti pembelajaran. Tahapan tersebut adalah tahapan pelaksanaan dan penutup.

Tahap pelaksanaan pada tahap pembelajaran ini guru bersama siswa melaksanakan Tanya jawab terkait materi yang telah disampaikan melalui metode pembelajaran dalam tahap ini pula kegiatan pembelajaran diterapkan dengan metode Round Robin dimana siswa yang ditunjuk dan diberi nomor setiapnya akan diberi pertanyaan dan disuruh langsung menjawab pertanyaan tanpa diberitahukan oleh teman sekelompoknya. Maka dengan penerapan metode Round Robin pada kelas VII.1 dapat mendorong siswa lebih membaca pembelajaran dan membangun pengetahuan siswa. Dalam penerapan metode Round Robin ini para siswa dapat bersaing dengan sehat dalam menjawab pertanyaan yang diberikan oleh guru.

Dengan penerapan metode Round Robin dapat menumbuhkan semangat agar tidak kalah dengan kelompok lain. Karena dalam penerpan metode Round Robin ini siswa harus menjawab pertanyaan dari guru dengan benar. Supaya kelompok mereka tidak kalah dengan kelompok yang lainnya. Kelebihan dari metode Round Robin ini adalah siwa lebih Dapat memotivasi dan mewujudkan para peserta didik boleh bergerak dan sekaligus dapat mengaktifkan dan menceriakan suasana. Dikarenakan siswa dibentuk dalam sebuah kelompok kecil untuk menjawab pertanyaan guru dengan dijawab oleh masing-masing siswa. Sehingga siswa bisa lebih kritis dan kreatif menjawab pertanyaan yang diberikan oleh guru. Hal ini dapat menambah pengetahuan siswa dan memudahkan siswa dalam mengingat materi yang diajarkan. Dibandingkan dengan pembelajaran konvensional yang siswanya hanya mendengarkan penjelasan guru tentang materi yang diberikan sehingga akan merasa bosan dan mengantuk mendengarkan guru menerangkan materi. Karena siswa tidak diberikan suatu rangsangan yang bisa merangsang ingatan mereka dalam materi pembelajaran. 
Oleh sebab itu, maka pemahaman antara kedua kelas tersebut sangat berbeda, hal ini dapat dilihat dari aktivitas siswa kelas eksperimen dengan penerapan metode Round Robin pemahaman siswa lebih baik dibandingkan siswa control dengan penerapan metode pembelajaran konvesional yang hanya mendengarkan penjelasan guru saja sehingga hanya terpaku pada guru saja. Bedasarkan analisis data diatas dapat disimpulkan bahwa terdapat pengaruh positif dari penerapan metode Round Robin pada siswa kelas VII.1 SMP N 2 Kec. Situjuah Limo Nagari dalam mata pelajaran IPS terpadu pada semester genap tahun ajaran 2017/2018.

\section{SIMPULAN}

Berdasarkan hasil penelitian yang telah penulis lakukan dapat disimpulkan bahwa penerapan metode Round Robin dapat berpengaruh postitif terhadap hasil belajar siswa kelas VII.1 dalam mata pelajaran IPS Terpadu dengan materi Masyarakat Indonesia pada Masa Praaksara, Hindu-Buddha, dan Islam dibandingkan dengan kelas VII.2 pada materi yang sama dengan metode konvensional.

\section{DAFTAR PUSTAKA}

Barkley, E. (2012). Collaborative Learning Techinique. Bandung: Nusa Indah.

Buswati. (2011), "Pembelajaran kooperatif teknik Round Robin untuk meningkatkan hasil belajar matematika murid kelas IV SDN 005 Petai Kecamatan Inuman Kabupaten Kuantan Singingi. Dengan menggunakan model pembelajaran kooperatif teknik Round Robin . Pekanbaru. Universitas Islam Negeri Sultan Syarif Kasim Riau

Depdiknas. (2006), Kurikulum Tingkat Satuan Pendidikan. Depdiknas. Jakarta. Dimyati \& Mudjiono. (2006). Belajar dan Pembelajaran. Jakarta: Rineka Cipta.

Djamarah. (2006), Strategi Belajar Mengajar, Jakarta: Rineka Cipta, Hamalik, O. (2005),Kurikulum dan Pembelajaran,BumiAksara, Jakarta Harahap, N. (1979), Teknik Penilaian Hasil Belajar, Bulan Bintang,Jakarta. Hartono,(2008), Statistik untuk Penelitian, Pustaka Belajar, Pekanbaru. Hisyam, Z. (2008). Srategi pembelajaran aktif. Yogyakarta: Insan Mandiri. Joko, S \& Surtikanti. (2008). Strategi belajar mengajar. Surakarta: UMS.

Lie, A. (2002).Cooperative Learning, Mempratikkan Cooperative Learning Di Ruang-Ruang Kelas, Jakarta: Garasindo.

Muhibbin, S. (2010).Psikologi pendidikan. Surakarta: Remaja Rosdakarya.

Milan, R. (2002). Pedekatan dan Metode Pembelajaran.strategi Pembelajaran Berbasis Kompetensi. Ciputat Gaung Persada Press. Malang: Depdiknas.

Rahmadani. (2014). STKIP Abdi Pendidikan Payakumbuh "Pengaruh penerapan metode Talking stick terhadap Hasil belajar siswa Mata Pelajaran IPS kelas VIII SMP N 3 Lintau,Payakumbuh 
Ridwan, A., S. (2013). inovasi Pembelajaran, Jakarta: Bumi Akasara.

Sandjaya,W. (2012), Perancanaan Dan Desain Sistem Pembelajaran, Jakarta: kencana Prenada Media Group.

Slameto. (2010). Belajar dan factor-faktor yang mempengaruhinya. Jakarta: Rineka Cipta.

Sobur, A. (2013). psikologi Umum. Bandung: Pustaka setia.Suprijono, A. (2013). Cooperative Learnig (teori dan aplikasi Palkem), Jakarta: Pustaka Pelajar.

Sugiyono. (2014). Metode Penelitian Kuantitatif Kualitatif. Bandung: Alfabeta

Syaiful, B., D. (2006). Guru dan anak Didik dalam interaksu edukatif, Jakarta: Rinerka Cipta.

Tim Prima Pena. (2007). Kamus Besar Bahasa Indonesia. Jakarta: Gita Media Press

Uno, H. (2013). “Belajar dengan Pendekatan PAILKEM”. Jakarta: BumiAksara 